\title{
DIETARY SUPPLEMENTATION OF LIPID AND INORGANIC PHOSPHORUS TO DEVELOP ENVIRONMENT-FRIENDLY FEED FOR YOUNG RED SEA BREAM, Pagrus major
}

\author{
M. S. A. Sarker* and S. Satoh ${ }^{1}$ \\ School of Agriculture and Rural Development, Bangladesh Open University \\ Gazipur-1705, Bangladesh
}

\begin{abstract}
An experiment was conducted to investigate the effects of dietary lipid and inorganic phosphorus supplementation on growth, retention and loading of phosphorus and nitrogen in young red sea bream. Two levels of lipid (190 and $250 \mathrm{~g} / \mathrm{kg}$ ) and two levels of phosphorus (14 and $19 \mathrm{~g} / \mathrm{kg}$ ) in the dry diets were tested. Four practical diets were formulated and coded as L0P0, L0P1, L1P0 and L1P1, respectively. Diet L0P0 was the fish meal-based (50\% fish meal) control diet without addition of lipid and phosphorus (P). Diet L0P1 was supplementation of $2 \%$ mono sodium phosphate to the LOP0 for providing 0.5 $\%$ P. Diet L1P0 was supplemented with 5\% soybean oil and L1P1 was formulated with the addition of 5\% soybean oil and $0.5 \%$ P. All diets were fed four times a day until satiation to duplicate groups of 25 fish (mean initial body weight $70.0 \pm 1.3 \mathrm{~g}$ ) during 12 -week feeding trial. At the conclusion of the experiment, growth and feed performance were lowest in the fish fed control diet, and significantly $(\mathrm{P}<0.05)$ improved by supplementing with $\mathrm{P}$. On the other hand, lipid supplementation did not show any statistical difference among the dietary groups. The $\mathrm{P}$ and nitrogen $(\mathrm{N})$ retention values for $\mathrm{P}$ supplemented diets were significantly $(\mathrm{P}<0.01)$ greater and reduced $(\mathrm{P}<0.01)$ both $\mathrm{N}$ and $\mathrm{P}$ excretion. This study demonstrated that, diet with the addition of inorganic $\mathrm{P}$ significantly improved fish growth, FCR, nutrient retention, and reduced both $\mathrm{N}$ and P loading while no addition of lipid is necessary.
\end{abstract}

Key words: Excretion, Lipid, Nitrogen, Phosphorus, Red sea bream, Retention

\section{INTRODUCTION}

Red sea bream is considered a potential species for aquaculture throughout the world and in Japan it constitute second largest aquaculture production after yellowtail (Koshio, 2002). However, with the increase in total culture, subsequent pollution of farm sites becomes more frequent. Excessive nutrient discharges at fish farms particularly $\mathrm{N}$ and $\mathrm{P}$

\footnotetext{
${ }^{1}$ Laboratory of Fish Nutrition, Department of Marine Biosciences, Tokyo University of Marine Science and Technology, Tokyo-108-8477, Japan

* Corresponding author. E-mail: sarkeralam@yahoo.com
} 
are of increasing concern. These discharges can lead to eutrophication of receiving water (Pillay, 1992; Ketola and Harland, 1993 and Skonberg et al., 1997) and the sources of P and $\mathrm{N}$ is fish feed (Cho and Bureau, 1997). Thus, the manipulation of feed formulation in such a way that nutrients in feed should be present at level that meet the nutrients requirement of fish is an efficient way to reduce environmental pollution in race way and cage culture (Cho and Bureau, 1997 and Talbot and Hole, 1994).

Nutritional strategy to reduce the waste load from aquaculture effluent is to produce high energy diet by reducing protein level and subsequently increasing fat level in the diet. The possibilities for reduced pollution load from fish feed are mostly related to improved feed conversion and reduced protein levels in the feed (Alsted, 1991). In high energy diets the energy concentration is increased to improve feed conversion. Satoh et al. (2004) reported that diets with additional lipid significantly reduced both $\mathrm{N}$ and $\mathrm{P}$ excretion by young yellowtail.

The necessity of $\mathrm{P}$ supplementation in a fish meal based diet has been reported at growing stage after juvenile (Masumoto, 2002) and fingerling red sea bream (Sarker et al., 2005 , 2007). But no report is yet available for young red sea bream. Feed quality improvement involving ways to retain dietary $\mathrm{P}$ is one of the main strategies to reduce environmental impact of aquaculture (Lall, 1989 and Sugiura and Hardy, 2000).

Fish meal (FM) is the source of most dietary $\mathrm{P}$ in fish diets, reported to be less available to some fish species (Watanabe et al., 1980) as a result of which, large amounts of $\mathrm{P}$ are excreted in feces, leading to wastage, and environmental pollution. FM is the conventional dietary protein sources in aquatic feeds and there is ever increasing demand for it with the expansion of aquaculture activities. It is the most expensive ingredient and its future availability is apprehensive. On the other hand, inorganic phosphorus from sodium phosphate is highly available to all fish.

The present study was thus aimed to investigate the possible effect of dietary lipid and inorganic $\mathrm{P}$ supplementation on growth, retention and excretion of $\mathrm{N}$ and $\mathrm{P}$ in young red sea bream fed fish meal based diets with an intention of developing less-polluting feed.

\section{MATERIALS AND METHODS}

\section{Experimental diets and design}

Two levels of lipid (190 and $250 \mathrm{~g} / \mathrm{kg}$ ) and two levels of phosphorus (14 and $19 \mathrm{~g} / \mathrm{kg}$ ) in the dry diets were tested. Four practical diets were formulated and coded as L0P0, L0P1, L1P0 and L1P1, respectively. Diet L0P0 was the fish meal-based (50\% fish meal) control diet without addition of lipid and P. Diet L0P1 was supplementation of $2 \%$ mono sodium phosphate to the L0P0 for providing $0.5 \%$ P. Diet L1P0 was supplemented with 5\% soybean oil and L1P1 was formulated with the addition of both $5 \%$ soybean oil and $0.5 \%$ P. (Table 1). The diets were pelleted using the laboratory pelletizer (AEZ12M, HiragaSeikakusho, Kobe, Japan), dried a vacuum freeze-drier (RLE-206, Kyowa Vacuum Tech., 
Saitama, Japan) and stored at $4^{\circ} \mathrm{C}$ until used. The experimental set-up was arranged in a $2 \times 2$ factorial experiment with two replications per treatment. Proximate and $\mathrm{P}$ compositions of each of the four practical diets are presented in Table 2. Phosphorus and lipid content of the diets varied with the additional P and lipid levels.

Table 1. Formulation of the experimental diets $(\mathrm{g} / \mathrm{kg})$

\begin{tabular}{l|c|c|c|c}
\hline \multirow{1}{*}{ Ingredients } & \multicolumn{4}{c}{ Diet code } \\
\cline { 2 - 5 } & L0P0 & L0 P1 & L1 P0 & L1 P1 \\
\hline Jack mackeral meal & 500.0 & 500.0 & 500.0 & 500.0 \\
Defatted soybean meal & 50.0 & 50.0 & 50.0 & 50.0 \\
Corn gluten meal & 50.0 & 50.0 & 50.0 & 50.0 \\
Wheat flour & 169.0 & 149.0 & 119.0 & 99.0 \\
Pregelatinized starch & 50.0 & 50.0 & 50.0 & 50.0 \\
Pollok liver oil & 135.0 & 135.0 & 135.0 & 135.0 \\
Soybean oil & 0.0 & 0.0 & 50.0 & 50.0 \\
P-free mineral mix & 10.0 & 10.0 & 10.0 & 10.0 \\
Na H $\mathrm{H}_{2}$ PO & 0.0 & 20.0 & 0.0 & 20.0 \\
Vitamin premixturec & 30.0 & 30.0 & 30.0 & 30.0 \\
Choline chloride & 5.0 & 5.0 & 5.0 & 5.0 \\
Vitamin E (50\%) & 1.0 & 1.0 & 1.0 & 1.0 \\
\hline
\end{tabular}

a P-free mineral mixture (g / 100g): $\mathrm{NaCl} 5.0, \mathrm{MgSO}_{4} \cdot 7 \mathrm{H}_{2} \mathrm{O} 74.5, \mathrm{FeC}_{6} \mathrm{H}_{5} \mathrm{O}_{7} \cdot n \mathrm{H}_{2} \mathrm{O} 12.5$, trace element mix. $b^{*} 5.0$, cellulose 3.0. $b^{*}(\mathrm{mg} / \mathrm{g})--\mathrm{ZnSO}_{4} \cdot 7 \mathrm{H}_{2} \mathrm{O} 353, \mathrm{MnSO}_{4} \cdot 5 \mathrm{H}_{2} \mathrm{O} 162, \mathrm{CuSO}_{4} \cdot 5 \mathrm{H}_{2} \mathrm{O} 31$,

$\mathrm{AlCl}_{3} \cdot 6 \mathrm{H}_{2} \mathrm{O} 10, \mathrm{CoCl} \cdot 6 \mathrm{H}_{2} \mathrm{O} 1, \mathrm{KIO}_{3} 3$, cellulose 440

The vitamin mix had the following components $(\mathrm{mg} / 100 \mathrm{~g})$--Thiamine hydrochloride 6, riboflavin 10 , pyridoxine hydrochloride 4 , cyanocobalamin 0.01 , ascorbic acid 500 , niacin 40 , Ca-pantothenate, 10, inositol 200, biotin 0.6, folic acid 1.5, $p$-aminobenzoic acid 5, vitamin $K_{3} 5$, vitamin A acetate 4000 IU, vitamin $D_{3} 4000$ IU

Table 2. Proximate and P compositions of the experimental diets ${ }^{*}$

\begin{tabular}{lccccc}
\hline \multicolumn{1}{c|}{ Diet code } & L0P0 & L0 P1 & L1 P0 & L1 P1 \\
\hline Moisture (g/kg) & 41 & 51 & 35 & 42 \\
Crude ash (g/kg) & 87 & 99 & 86 & 96 \\
Crude protein (g/kg) & 487 & 489 & 467 & 465 \\
Crude lipid (g/kg) & 191 & 192 & 252 & 247 \\
Gross energy (MJ/kg) & 23.3 & 23.4 & 24.7 & 24.4 \\
Protein/GE ratio (g/MJ) & 20.5 & 20.8 & 18.9 & 19.1 \\
P (mg/g) & 13.8 & 18.8 & 13.6 & 18.5 \\
\hline
\end{tabular}

${ }^{*}$ Mean values presented as dry matter basis 


\section{Fish, experimental conditions, and feeding}

Young red sea bream Pagrus major were obtained from Seiho Suisan Co. Ltd. (Mie, Japan) and fed commercial red sea bream feed prior to the start of the experiment. Twenty five fish (average weight $70.0 \pm 1.3 \mathrm{~g}$ ) were randomly distributed in each well-aerated 60-1 glass tanks with two replications. The feeding trial was conducted in re-circulated artificial seawater (Sea Life ${ }^{\circledR}$, Tokyo, Japan) at a flow rate of $700-800 \mathrm{ml} / \mathrm{min}$. The water renewal rate in the system was $50 \%$ in every week. Important water quality parameters such as temperature, $\mathrm{pH}$, salinity were monitored daily and dissolved oxygen was measured fortnightly. All the parameters observed were found to be within the acceptable limits for fish culture. Average daily water temperature was $26 \pm 1.13^{\circ} \mathrm{C}$. The fish were fed four times a day until near satiation for 12 weeks.

\section{Sample collection and chemical analyses}

Initial weight data was obtained at the start of the experiment and growth of fish was measured every third weeks during the experimental period. Upon termination of the experiment, 5 fish from each tank were randomly selected and sacrificed for the chemical analyses of the whole body. Whole body samples were pooled from 5 fish and minced by a centrifugal mill (Retsch ZM 1, Germany) fitted with a $0.25 \mathrm{~mm}$ screen. The homogenate was collected and kept at $-20^{\circ} \mathrm{C}$ until analysis. Chemical analysis of the diets, whole body were performed as describe by Satoh et al. (1987c). Samples for P were digested in nitric acid using the MLS-1200 Mega Microwave Digestion System (Italy). Concentration of P was analyzed by a visible light spectrophotometry (Shimadzu, UV 265 FW, Kyoto, Japan) at $750 \mathrm{~nm}$.

\section{Statistical analyses}

Results were analyzed using one-way and two-way ANOVA (Systat 8.0, SPSS, Chicago, USA). Differences between treatments were compared by Tukey's test. Values were considered significant at $\mathrm{P}<0.05$.

\section{RESULTS AND DISCUSSION}

The results of overall growth performance and feed utilization by the fish are presented in Table 3 and 4. Dietary lipid level did not show any significant difference on weight gain, specific growth rate (SGR) and feed conversion ratio (FCR) throughout the rearing period. On the other hand, P supplementation significantly improved the wait gain, SGR and FCR. Two-way ANOVA for diet groups showed significant $(\mathrm{P}<0.05)$ effects of weight gain, SGR and FCR in P levels while no significant effect in lipid levels and they did not show significant interaction effects (Table 4). In the present study, the higher growth of fish with addition of $\mathrm{P}$ compared to the group without $\mathrm{P}$ supplement indicate that $\mathrm{P}$ derived from fish meal alone could not satisfy the requirement of young red sea bream. Thus, this fish perhaps needed additional water soluble P. This is in agreement with the previous reports in juvenile and fingerling red sea bream (Satoh et al., 1998 and Sarker et al., 2005, 2007). The observations in the present study on FCR, weight gain, SGR also 
indicate (Table 3) that $\mathrm{P}$ supplementation is necessary in the diet of young red sea bream. Dietary $\mathrm{P}$ requirement for optimum growth, feed utilization and bone mineralization ranging from 5 to $8 \mathrm{~g} / \mathrm{kg}$ has been reported for rainbow trout and other fish (Ogino and Takeda, 1978; Watanabe et al., 1980 and Sugiura et al., 2000). In the present study the dietary $\mathrm{P}$ in all the treated groups was at par with the minimum level of dietary $\mathrm{P}$ requirement for red sea bream, which is reported to be $6.8 \mathrm{~g} / \mathrm{kg}$, dry diet (Sakamoto and Yone, 1978).

Proximate compositions of the fish whole body are presented in Table 5. Proximate composition of the fish did not show any significant difference among the treatments (Table 5). Whole body P content of fish was lowest in the LOP0 group and it was significantly increased with the additional $\mathrm{P}$ while no changed with additional lipid. Whole body lipid content of the lipid supplemented group was higher than that of the group fed with other diets (Table 5). Higher carcass lipid and P contents in the diets supplemented with lipid and $\mathrm{P}$ in this study which suggests that they are retained more in the young red sea bream.

Table 3. Growth and feed performance in red sea bream cultured for 12 weeks

\begin{tabular}{l|c|c|c|c}
\hline \multicolumn{1}{c|}{ Diet code } & L0P0 & L0 P1 & L1 P0 & L1 P1 \\
\hline Weight gain (g) & $43.12 \pm 4^{\mathrm{b}}$ & $83.35 \pm 2^{\mathrm{a}}$ & $41.68 \pm 2^{\mathrm{b}}$ & $94.16 \pm 3^{\mathrm{a}}$ \\
SGR $^{*} \%$ per day) & $0.76 \pm 0.04^{\mathrm{b}}$ & $1.33 \pm 0.02^{\mathrm{a}}$ & $0.78 \pm 0.03^{\mathrm{b}}$ & $1.41 \pm 0.05^{\mathrm{a}}$ \\
FCR $^{* *}$ & $1.59 \pm 0.02^{\mathrm{a}}$ & $0.96 \pm 0.02^{\mathrm{b}}$ & $1.78 \pm 0.03^{\mathrm{a}}$ & $0.98 \pm 0.01^{\mathrm{b}}$ \\
\hline
\end{tabular}

Values are presented as mean \pm S.D. Means in a row not sharing the same superscript letters are significantly different $(\mathrm{P}<0.05)$

* Specific growth rate $=100 \times(\ln$ final body weight $-\ln$ initial body weight $) /$ days

** Feed conversion ratio (feed consumption/weight gain)

Table 4. Growth and feed performance in red sea bream cultured for 12 weeks $(2 \times 2$ ANOVA)

\begin{tabular}{l|c|c|c}
\hline \multicolumn{1}{c}{ Diet code } & Weight gain & SGR $^{*}$ & $\mathrm{FCR}^{* *}$ \\
\hline Lipid level & NS & NS & NS \\
P level & $<0.05$ & $<0.05$ & $<0.05$ \\
Lipid $\times$ P interaction & NS & NS & NS \\
\hline
\end{tabular}

* Specific growth rate $=100 \times(\ln$ final body weight $-\ln$ initial body weight $) /$ days

** Feed conversion ratio (feed consumption/weight gain)

NS = Not significant; Values were considered significant as $\mathrm{P}<0.05$

Retention and excretion of $\mathrm{P}$ are presented in Table 6 and 7. Retention of $\mathrm{P}$ in young red sea bream was elevated significantly with additional $\mathrm{P}$ compared to the control group. Excretion of $\mathrm{P}$ by red sea bream was decreased significantly $(\mathrm{P}<0.01)$ with $\mathrm{P}$ supplemented groups compared to the control group (Table 6). Retention rate of $\mathrm{P}$ are significantly increased with the additional $P$ which resulted in significant reduction of its excretion (Table 6). This is in agreement with the previous reports in juvenile and 
fingerling red sea bream (Satoh et al., 1998 and Sarker et al., 2005, 2007). Two-way ANOVA for diet groups showed significant effects $(\mathrm{P}<0.05)$ of retention and excretion of phosphorus in $\mathrm{P}$ levels while no significant effect in lipid levels and they did not show significant interaction effects (Table 7).

Table 5. Proximate and P compositions of red sea bream whole body at start and fed the experimental diets for 12 weeks*

\begin{tabular}{l|c|c|c|c|c}
\hline \multicolumn{1}{c}{ Diet code } & Initial & L0P0 & L0P1 & L1P0 & L1P1 \\
\hline Moisture $(\mathrm{g} / \mathrm{kg})$ & 681 & $670 \pm 1^{\mathrm{a}}$ & $656 \pm 1^{\mathrm{a}}$ & $667 \pm 2^{\mathrm{a}}$ & $654 \pm 1^{\mathrm{a}}$ \\
Crude ash $(\mathrm{g} / \mathrm{kg})$ & 44.9 & $47.1 \pm 0.2^{\mathrm{a}}$ & $47.9 \pm 0.4^{\mathrm{a}}$ & $46.1 \pm 0.6^{\mathrm{a}}$ & $48.4 \pm 0.1^{\mathrm{a}}$ \\
Crude protein $(\mathrm{g} / \mathrm{kg})$ & 168 & $160 \pm 2^{\mathrm{a}}$ & $173 \pm 1^{\mathrm{a}}$ & $170 \pm 1^{\mathrm{a}}$ & $174 \pm 1^{\mathrm{a}}$ \\
Crude lipid $(\mathrm{g} / \mathrm{kg})$ & 106 & $108 \pm 1^{\mathrm{a}}$ & $123 \pm 2^{\mathrm{a}}$ & $117 \pm 2^{\mathrm{a}}$ & $126 \pm 1^{\mathrm{a}}$ \\
P $(\mathrm{mg} / \mathrm{g})$ & 8.33 & $8.37 \pm 0.1^{\mathrm{a}}$ & $8.53 \pm 0.0^{\mathrm{a}}$ & $8.38 \pm 0.1^{\mathrm{a}}$ & $8.87 \pm 0.1^{\mathrm{a}}$ \\
\hline
\end{tabular}

* Values are presented as mean \pm S.D. $(n=$ pooled samples of 5 fish/tank)

Means in a column not sharing the same superscript letters are significantly different $(\mathrm{P}<0.05)$

Table 6. Retention and excretion of phosphorus by red sea bream fed the experimental diets for 12 weeks*

\begin{tabular}{l|c|c}
\hline \multicolumn{1}{c|}{ Diet code } & Phosphorus retention $(\%)^{1}$ & ${\text { Phosphorus excretion }(\mathrm{kg} / \mathrm{t})^{2}}^{1}$ \\
\hline L0P0 & $36.98 \pm 1.2^{\mathrm{b}}$ & $13.81 \pm 0.4^{\mathrm{a}}$ \\
L0P1 & $49.02 \pm 0.3^{\mathrm{a}}$ & $9.20 \pm 0.1^{\mathrm{b}}$ \\
L1P0 & $33.67 \pm 0.1^{\mathrm{b}}$ & $16.07 \pm 0.2^{\mathrm{a}}$ \\
L1P1 & $56.21 \pm 0.9^{\mathrm{a}}$ & $7.94 \pm 0.2^{\mathrm{b}}$ \\
\hline
\end{tabular}

* Values are presented as mean \pm S.D. $(n=$ pooled samples of 5 fish/tank)

Means in a column not sharing the same superscript letters are significantly different $(\mathrm{P}<0.05)$

1 Retention $(\%)=\{($ Final nutrient content - initial nutrient content $) /$ nutrient intake $\} \times 100$

${ }^{2}$ Excretion $(\mathrm{kg} / \mathrm{t})=[\{\mathrm{FCR} \times$ nutrient in $\operatorname{diet}(\mathrm{g})-$ nutrient retained in fish $(\mathrm{g})\} /$ production $(\mathrm{t})] \times 100$

Table 7. Retention and excretion of phosphorus by red sea bream fed the experimental diets for 12 weeks $(2 \times 2$ ANOVA) period

\begin{tabular}{lcc}
\hline \multicolumn{1}{c|}{ Diet code } & Phosphorus retention $(\%)$ & Phosphorus excretion $(\mathrm{kg} / \mathrm{t})$ \\
\hline Lipid level & NS & NS \\
P level & $<0.05$ & $<0.05$ \\
Lipid $\times$ P interaction & NS & NS \\
\hline
\end{tabular}

NS = Not significant; Values were considered significant as $\mathrm{P}<0.05$

Retention and excretion of $\mathrm{N}$ are presented in Table 8 and 9. Retention of $\mathrm{N}$ in young red sea bream was elevated significantly $(\mathrm{P}<0.05)$ with additional $\mathrm{P}$ compared to control group. Excretion of $\mathrm{N}$ by red sea bream was decreased significantly $(\mathrm{P}<0.01)$ with $\mathrm{P}$ supplemented groups compared to the control group (Table 8). Retention rate of $\mathrm{N}$ 
significantly $(\mathrm{P}<0.01)$ increased with the additional $\mathrm{P}$ which resulted in significant $(\mathrm{P}<0.01)$ reduction of its loading (Table 8$)$. This is in agreement with the previous reports in juvenile and fingerling red sea bream (Satoh et al., 1998 and Sarker et al., 2005, 2007). Two-way ANOVA for diet groups showed significant effects of retention and excretion of $\mathrm{N}$ in $\mathrm{P}$ levels while no significant effect in lipid levels and they did not show significant interaction effects (Table 9).

Table 8. Retention and excretion of nitrogen by red sea bream fed the experimental diets for 12 weeks*

\begin{tabular}{l|c|c}
\hline Diet code & Nitrogen retention $(\%)^{1}$ & ${\text { Nitrogen excretion }(\mathrm{kg} / \mathrm{t})^{2}}^{1}$ \\
\hline L0P0 & $19.05 \pm 0.3^{\mathrm{b}}$ & $100.27 \pm 1.7^{\mathrm{a}}$ \\
L0P1 & $38.77 \pm 0.4^{\mathrm{a}}$ & $45.79 \pm 0.3^{\mathrm{b}}$ \\
L1P0 & $20.77 \pm 0.3^{\mathrm{b}}$ & $105.45 \pm 2.1^{\mathrm{a}}$ \\
L1P1 & $40.51 \pm 0.1^{\mathrm{a}}$ & $43.38 \pm 0.5^{\mathrm{b}}$ \\
\hline
\end{tabular}

*Values are presented as mean \pm S.D. $(\mathrm{n}=$ pooled samples of 5 fish/tank)

Means in a column not sharing the same superscript letters are significantly different $(\mathrm{P}<0.05)$

${ }^{1}$ Retention $(\%)=\{($ Final nutrient content - initial nutrient content $) /$ nutrient intake $\} \times 100$

${ }^{2}$ Excretion $(\mathrm{kg} / \mathrm{t})=[\{\mathrm{FCR} \times$ nutrient in diet $(\mathrm{g})-$ nutrient retained in fish $(\mathrm{g})\} /$ production $(\mathrm{t})] \times 100$

Table 9. Retention and excretion of nitrogen by red sea bream fed the experimental diets for 12 weeks $(2 \times 2$ ANOVA)

\begin{tabular}{lc|c}
\hline \multicolumn{1}{c|}{ Diet code } & Nitrogen retention $(\%)$ & Nitrogen excretion $(\mathrm{kg} / \mathrm{t})$ \\
\hline Lipid level & NS & NS \\
P level & $<0.05$ & $<0.05$ \\
Lipid $\times$ P interaction & NS & NS
\end{tabular}

NS = Not significant; Values were considered significant as $\mathrm{P}<0.05$

The increased $\mathrm{P}$ and $\mathrm{N}$ retention with the diets with additional $\mathrm{P}$ fed groups in this experiment might have induced better growth and FCR. Again because of the reduced excretion of $\mathrm{P}$ and $\mathrm{N}$, the possible loading to the environment can be decreased. Further, it was clarified through this study that $\mathrm{P}$ incorporation in the diets showed the best result. Retention efficiencies of nutrients such as $\mathrm{P}$ and $\mathrm{N}$ are important for evaluation of feed quality and this might change according to fish weight, amount of feed consumed (Lall, 1991 and Cho et al., 1994). No report is available yet using inorganic P in young red sea bream diet.

It may be concluded from this study that inorganic $\mathrm{P}$ supplementation improved fish growth, FCR and retention of $\mathrm{P}$ and $\mathrm{N}$ which resulted in significant reduction of both $\mathrm{P}$ and $\mathrm{N}$ excretion. The diet supplemented with $5 \%$ soybean oil did not show significant difference in all the parameters studied with the diets. Hence, this study demonstrated that dietary inorganic P supplementation is needed in the fishmeal based diets of young red sea bream This study will certainly contribute to develop the much desired 
environment-friendly feed for red sea bream; however, more investigations in this concern integrating different size/age groups of this fish are warranted.

\section{ACKNOWLEDGEMENTS}

This study was partly supported by the Grants-in-Aid for Scientific research of the Japanese Ministry of Education, Culture, Sports, Science, and Technology (MEXT) and the Grant of the Fisheries Agency of Japan.

\section{REFERENCES}

Alsted, N. S. 1991. Studies on discharges from fish farms by modification of the diet. In: Cowey, C. B. and Cho, C. Y., (eds.) Nutritional Strategies and Aquaculture Waste, Proceedings of the First International Symposium on Nutritional Strategies in Management of Aquaculture Waste, University of Guelph, Guelph, Ontario, Canada, pp. 77-89.

Cho, C. Y., Hynes, J. D., Wood, K. R. and Yoshida, H. K. 1994. Development of high-nutrient-dense, low-pollution diets and prediction of aquaculture waste using biological approaches. Aquaculture, 124: 293- 305.

Cho, C. Y. and Bureau, D. P. 1997. Reduction of waste output from salmonid aquaculture through feeds and feeding. Prog. Fish-Cult., 59: 155-160.

Crawford, R. D. 1995. Proposed role for a combination of citric acid and ascorbic acid in the production of dietary iron overload: a fundamental cause of disease. Biochem. Mol. Med., 54: $1-11$.

Cross, H. S., Debiec, H. and Peterlik, M. 1990. Mechanism and regulation of intestinal phosphate absorption. Miner. Electrolyte. Metab., 16: 115-124.

Davis, D. A. and Gatlin III, D. M. 1996. Dietary mineral requirements of fish and marine crustaceans. Rev. Fish. Sci., 4: 75-99.

Francis, G., Makkar, H. P. S. and Becker, K. 2001. Antinutritional factors present in plant-derived alternate fish feed ingredients and their effects in fish. Aquaculture, 199: 197-227.

Hardy, R. W. and Shearer, K. D. 1985. Effect of dietary calcium phosphate and zinc supplementation on whole body zinc concentration of rainbow trout (Salmo gairdneri). Can. J. Fish. Aquat. Sci., 42: 181-184.

Hardy, R. W., Sullivan, C. V. and Koziol, A. M. 1987. Absorption, body distribution, and excretion of dietary zinc by rainbow trout (Salmo gairdneri). Fish Physiol. Biochem., 3: 133-143.

Ketola, H. G. and Harland, B. F. 1993. Influence of phosphorus in rainbow trout diets on phosphorus discharges in effluent water. Trans. Am. Fish. Soc., 122: 1120-1126.

Koshio, S. 2002. Red sea bream, Pagrus major. In: Webster, C.D., Lim, C.E. (eds.), Nutrient Requirements and Feeding of Finfish for Aquaculture. CABI Publishing, New York, USA. pp. 51-63.

Lall, S. P. 1989. The minerals. In: Halver, J. E. (ed.), Fish Nutrition, 2nd edn., Academic Press, San diego, CA, pp. 219-257.

Lall, S. P. 1991. Digestibility, metabolism and excretion of dietary phosphorus in fish. In: Cowey, C. B., Cho, C. Y. (eds.), Nutritional Strategies and Aquaculture Waste. Proceedings of the First International Symposium on Nutritional Strategies in Management of Aquaculture Waste. University of Guelph, Guelph, Ontario, Canada. pp. 21-35. 
Masumoto, T. 2002. Yellowtail, Seriola quinqueradiata. In: Webster, C. D., Lim, C. E. (Eds.), Nutrient Requirements and Feeding of Finfish for Aquaculture. CABI Publishing, New York, USA. pp. 131-146.

Ogino, C. and Takeda, H. 1978. Requirements of rainbow trout for dietary calcium and phosphorus. Bull. Jpn. Soc. Sci. Fish., 44: 1019 -1022.

Pillay, T. V. R. 1992. Aquaculture and the Environment. John Wiley \& Sons Inc., New York, USA.

Sakamoto, S., and Yone, Y. 1978. Effect of dietary phosphorus level on chemical composition of red sea bream. Nippon Suisan Gakkaishi, 4: 227-229.

Sarker, M. S. A., Satoh, S. and Kiron, V. 2005. Supplementation of citric acid and amino acid-chelated trace element to develop environment-friendly feed for red sea bream, Pagrus major. Aquaculture, 248: 3-11.

Sarker, M. S. A., Satoh, S. and Kiron V. 2007. Inclusion of citric acid and/or amino acid-chelated trace elements in alternate plant protein source diets affects growth and excretion of nitrogen and phosphorus in red sea bream Pagrus major. Aquaculture, 262: 436-443.

Satoh, S., Cho, C. Y. and Watanabe, T. 1992. Effect of fecal retrieval timing on digestibility of nutrients in rainbow trout diet with the Guelph and TUF feces collection systems. Nippon Suisan Gakkaishi, 58: 1123-1127.

Satoh, S., Sarker, M. S. A., Satoh, K. and Kiron, V., 2004. Effects of dietary lipid and phosphorus levels on nitrogen and phosphorus excretion in young yellowtail Seriola quinqueradiata : A preliminary observation. Fish. Sci., 70: 1082-1088.

Satoh, S., Ishida, R., Takeuchi, T., Watanabe, T. and Seikai, T. 1998. Necessity of mineral supplement to fish meal based red sea bream feed. Suisanzoshoku, 46: 535-540.

Skonberg, D. L., Yoge, L., Hardy, R. W. and Dong, F. 1997. Metabolic response of dietary phosphorus intake in rainbow trout (Oncorhynchus mykiss). Aquaculture, 157: 11-24.

Sugiura, S. H. and Hardy, R. W. 2000. Environmentally friendly feeds. In: Stickney, R. R. (ed.), Encyclopedia of Aquaculture. Wiley-Interscience, New York. pp. 299-310.

Sugiura, S. H., Dong, F. M. and Hardy, R. W. 1998. Primary responses of rainbow trout to dietary phosphorus concentrations. Aquacult. Nutr., 6: 235-246.

Sugiura, S. H., Babbitt, J. K., Dong, F. M. and Hardy, R. W. 2000. Utilization of fish and animal byproduct meals in low-pollution feeds for rainbow trout Oncorhynchus mykiss (Walbaum). Aquacult. Res., 31: 585-593.

Talbot, C. and Hole, R. 1994. Fish diets and the control of eutrophication resulting from aquaculture. J. Appl. Ichthyol., 10: 258 -270.

Watanabe, T., Murakami, A., Tekeuchi, L., Nose, T. and Ogino, C. 1980. Requirement of chum salmon held in freshwater for dietary phosphorus. Nippon Suisan Gakkaishi, 46:361-367. 